\title{
In vitro shoot multiplication of the biodiesel plant Jatropha curcas L. through direct organogenesis
}

\author{
M. A. K. M. S ${ }^{*}$ Hassan*a, N. Begum $^{2}$, L. S. Bari ${ }^{2}$ and M. A. A. Jahan ${ }^{2}$ \\ ${ }^{1}$ Department of Botany, Savar College, Savar, Dhaka-1340, \\ ${ }^{2}$ Biological Research Division, BCSIR Laboratories, Dhaka-1205, Bangladesh
}

\begin{abstract}
An efficient protocol was established for in vitro shoot multiplication of the biodiesel plant, Jatropha curcas L. (Euphorbiaceae) through direct organogenesis using shoot tip and nodal explants. Best shoot induction was observed on MS basal medium supplemented with 1.5 $\mathrm{mg} / \mathrm{l} \mathrm{BAP}+0.5 \mathrm{mg} / 1 \mathrm{NAA}$, in which $86.2 \%$ of nodal explants responded to produce maximum number $(7.2 \pm 0.68)$ of shoots per culture. In vitro raised shoots rooted on half strength MS medium with $1.0 \mathrm{mg} / \mathrm{l} \mathrm{IAA}$. The survival rate of regenerated plantlets was $85 \%$.
\end{abstract}

Keywords:: Jatropha curcas; Biodiesel plant; Multiplication; Organogenesis; Acclimatization

\section{Introduction}

Jatropha curcas L. commonly known as 'Jamal Gota' belongs to Euphorbiaceae, an evergreen shrub or small tree with long-petioled ovate-cordate lobed leaves, small flowers in axillary cymes and angular fruits, grows wild in waste places throughout the Bangladesh (Ghani, 2003). Seeds and seed oil are used as purgative, more drastic than those of Ricinus communis; they are used against warts and cancers; seed oil is applied topically in rheumatism, herpes and pruritis; sap of the plant is used to cure toothache and as a styptic; pounded leaves and juice are applied to wounds and ulcers and also used in the treatment of scabies, eczema and ringworm; roots are used as emetic and purgative (Ghani, 2003).

Jatropha curcas a drought tolerant perennial plant species has received global attention due to its seed which contains $40-50 \%$ semi drying oil; it is used as an efficient substitute for diesel fuel (Takeda, 1982; Banerji et al. 1985; Martin and Mayeux, 1985; Muhlbauer et al. 1998). Realizing the importance of renewable energy sources, countries like Cape Verde, Madagascar, Nicaragua, Brazil, Mali etc. are using the seeds of Jatropha curcas for large scale production of biodiesel (Heller, 1996). The center of origin of this species is known to be South America (Brazil); later is spread all tropical regions (Dehgan and Webster, 1979).
The oil yield from kernels is estimated between 46 and 58\% derived from semi-drying oil (iodine value 93 - 100\%) containing mainly oleic (37 - 63\%), linoleic (19 - 40\%) and palmitic (12 - 17\%) acids as constituents of fatty acids. Medicinally the oil is used as a purgative and emetic and against coetaneous disease (Godbole et al.,1966). It is also used for burning and spinning in the manufacture of hard soaps and candles, paint and lubricants (Roy, 1990).

The seeds of Jatropha curcas are of great commercial interest in the recent decade for fuel; to exploit the oil at a maximum extent, it is necessary to propagate and select the best genotype for oil contents and quality; the genetic diversity in the natural population appears narrow since no remarkable morphological differences have been observed (Sujatha and Mukta, 1996). In order to meet the demand of fuel in the near future, the development of appropriate technology for the rapid regeneration at a large scale of this species is essential. The conventional method of propagation through seeds will not solve the problem; under this situation in vitro regeneration of this species through tissue culture offers a powerful method to overcome the problem (Kalimuthu et al., 2007). There have been a few reports on the establishment of micropropagation protocol for Jatropha podagrica (Spera et al., 1997), Jatropha integarrima L. (Sujatha and Pabakaran, 2003; Sujatha and Dhingra, 1993) and Jatropha curcas L.

*Corresponding author. e-mail: <aksayeedsc@gmail.com> 
(Kalimuthu et al. 2007). Protocols developed for micropropagation of Jatropha species by Sujatha and Mukta (1996), Sujatha and Pabakaran (2003), Rojore and Batra (2005), Sujatha et al. (2005) were not promising because the multiplication rate was low. In vitro propagation has been proved as a potential technology for mass scale production of medicinal plant species (Hassan and Roy, 2005; Lui and Li, 2001; Martin, 2002; 2003). It is important, therefore to develop an efficient micropropagation technique for the biodiesel plant, Jatropha curcas L. for rapidly disseminate superior clones. Kalimuthu et al. (2007) reported that the biodiesel plant, Jatropha curcas L. was micropropagated using nodal explants on MS supplemented with $1.5 \mathrm{mg} / 1$ BAP, $0.5 \mathrm{mg} / 1 \mathrm{Kn}$ and $0.1 \mathrm{mg} / \mathrm{l}$ IAA and somatic embryos were induced directly from green cotyledon explants on MS fortified with $2.0 \mathrm{mg} / \mathrm{l} \mathrm{BAP}$. The present study was therefore, undertaken to develop a protocol for in vitro shoot multiplication of the biodiesel plant, Jatropha curcas L. through direct organogenesis using shoot tip and nodal explants.

\section{Materials and Methods}

Jatropha curcas L. at Medicinal Plants Garden of Bangladesh Council of Scientific and Industrial Research (BCSIR), Dhaka, was used as a source of explants. Shoot tip and nodal explants with a single axillary bud were used for this purpose. The explants were washed thoroughly under running tap water, pre-soaked in Tricks liquid detergent for about $30 \mathrm{~min}$, wiped with cotton and dipped in $70 \%(\mathrm{v} / \mathrm{v})$ ethanol for $1 \mathrm{~min}$. They were then surface-sterilized with $0.1 \%(\mathrm{w} / \mathrm{v})$ mercuric chloride for $5 \mathrm{~min}$, followed by five times rinse with sterile distilled water under laminar air flow cabinet. The surface-sterilized explants were cut into 1-1.5 $\mathrm{cm}$ length containing a single node with an axillary bud or a shoot tip with an apical bud. The explants were placed vertically on the culture medium. The new shoots induced from the in vitro cultures were further used as an explants for adventitious shoot regeneration.

MS (Murashige and Skoog, 1962) basal medium was used for shoot proliferation and adventitious shoot regeneration and half strength MS was used for in vitro root induction. All media were supplemented with $30 \mathrm{~g} / 1$ sucrose, $7 \mathrm{~g} / 1$ agar (Difco) and dispensed into $15 \times 150 \mathrm{~mm}$ culture tubes and $250 \mathrm{ml}$ conical flasks. The $\mathrm{pH}$ of the media was adjusted to 5.8 before autoclaving at $1.9 \mathrm{~kg} / \mathrm{cm}^{2}$ pressure at $121^{\circ} \mathrm{C}$ for $20 \mathrm{~min}$. The cultures were incubated for a $16 \mathrm{~h}$ photoperiod at $24 \pm 2{ }^{\circ} \mathrm{C}$ under $1200 \mathrm{lux} / \mathrm{m} 2$ fluorescent light.

Shoot proliferation from shoot tip and nodal explants was obtained in two separate sets of experiments. In the first experiment $0.1-2.0 \mathrm{mg} / \mathrm{L}$ BAP were incorporated into MS media to select the best cytokinin for the response of shoot

Table I. Effect of BAP, NAA and IAA in MS on morphogenic response of Jatropha curcas shoot tips and nodal explants

\begin{tabular}{|c|c|c|c|c|c|c|}
\hline \multicolumn{3}{|c|}{ Growth regulators $(\mathrm{mg} / \mathrm{l})$} & \multicolumn{2}{|c|}{ Shoot tips } & \multicolumn{2}{|c|}{ Nodal explants } \\
\hline BAP & NAA & IAA & $\begin{array}{l}\% \text { of explants } \\
\text { forming shoots }\end{array}$ & $\begin{array}{l}\text { Mean No. of } \\
\text { shoot/explant }\end{array}$ & $\begin{array}{l}\% \text { of explants } \\
\text { forming shoots }\end{array}$ & $\begin{array}{l}\text { Mean No. of } \\
\text { shoot/explant }\end{array}$ \\
\hline 0.1 & & & $43.4 \pm 0.87 \mathrm{~h}$ & $1.6 \pm 0.77 \mathrm{~d}$ & $58.6 \pm 1.70 \mathrm{i}$ & $2.4 \pm 0.91 \mathrm{de}$ \\
\hline 0.3 & & & $52.6 \pm 1.66 \mathrm{fg}$ & $2.2 \pm 0.63 \mathrm{cdef}$ & $64.4 \pm 0.51 \mathrm{~g}$ & $2.6 \pm 0.66 \mathrm{~d}$ \\
\hline 0.5 & & & $53.4 \pm 1.57 \mathrm{f}$ & $2.6 \pm 0.76 \mathrm{~cd}$ & $67.2 \pm 2.47 \mathrm{ef}$ & $2.6 \pm 0.72 \mathrm{~d}$ \\
\hline 1.0 & & & $57.6 \pm 2.16 \mathrm{ef}$ & $2.6 \pm 0.45 \mathrm{~cd}$ & $71.4 \pm 2.38 \mathrm{~d}$ & $3.4 \pm 1.18 \mathrm{cde}$ \\
\hline 1.5 & & & $64.8 \pm 2.58 \mathrm{c}$ & $3.4 \pm 0.72 \mathrm{bc}$ & $77.6 \pm 2.16 \mathrm{~b}$ & $3.4 \pm 0.82 \mathrm{cde}$ \\
\hline 2.0 & & & $61.4 \pm 2.87 \mathrm{de}$ & $2.8 \pm 0.76 \mathrm{c}$ & $63.6 \pm 1.84 \mathrm{gh}$ & $4.6 \pm 1.14 \mathrm{bc}$ \\
\hline 0.5 & 0.1 & & $52.6 \pm 0.87 \mathrm{fg}$ & $2.2 \pm 0.59 \mathrm{cdef}$ & $68.6 \pm 1.70 \mathrm{e}$ & $3.6 \pm 0.91 \mathrm{~cd}$ \\
\hline 1.0 & 0.2 & & $68.2 \pm 1.66 \mathrm{~b}$ & $3.6 \pm 0.77 \mathrm{~b}$ & $73.6 \pm 0.51 \mathrm{c}$ & $4.4 \pm 0.66 \mathrm{bcd}$ \\
\hline 1.5 & 0.5 & & $72.4 \pm 2.89 \mathrm{a}$ & $4.8 \pm 0.92 \mathrm{a}$ & $86.2 \pm 1.80$ a & $7.2 \pm 0.68 \mathrm{a}$ \\
\hline 2.0 & 0.5 & & $62.2 \pm 1.96 \mathrm{~d}$ & $3.0 \pm 0.63 \mathrm{bcd}$ & $71.2 \pm 2.47 \mathrm{de}$ & $4.8 \pm 0.95 b$ \\
\hline 0.5 & & 0.1 & $48.8 \pm 1.77 \mathrm{~g}$ & $2.4 \pm 0.45 \mathrm{cde}$ & $52.2 \pm 0.66 \mathrm{j}$ & $2.2 \pm 0.76 \mathrm{def}$ \\
\hline 1.0 & & 0.2 & $56.6 \pm 1.66 \mathrm{efg}$ & $3.0 \pm 0.39 \mathrm{bcd}$ & $66.8 \pm 2.14 \mathrm{f}$ & $3.2 \pm 0.51 \mathrm{cdef}$ \\
\hline 1.5 & & 0.5 & $61.0 \pm 1.14$ ef & $3.6 \pm 0.65 b$ & $77.6 \pm 2.10 \mathrm{~b}$ & $4.4 \pm 0.91 \mathrm{bcd}$ \\
\hline 2.0 & & 0.5 & $58.4 \pm 1.96 \mathrm{e}$ & $2.2 \pm 0.45 \mathrm{cdef}$ & $62.6 \pm 1.63 \mathrm{~h}$ & $3.8 \pm 0.76 \mathrm{c}$ \\
\hline
\end{tabular}

Mean values \pm SE followed by the same letter within a column are not significantly different at $\mathrm{p}<0.05$ by DMRT. 
induction. In the second set, combination of BAP (0.5-2.0 $\mathrm{mg} / \mathrm{L})$ with NAA $(0.1-0.5 \mathrm{mg} / \mathrm{L})$ and BAP $(0.5-2.0 \mathrm{mg} / \mathrm{L})$ with IAA (0.1-0.5 mg/L) were assessed for shoot multiplication. Number of new proliferated shoot of in each culture was recorded after every week of inoculation. For in vitro rooting, individual shoots $(3-5 \mathrm{~cm})$ were excised from the proliferated shoots and implanted onto half strength MS with different concentrations and combinations of NAA, IBA and IAA.

The rooted plants were washed to remove agar gel adhered to the roots and transplanted to plastic pots with soil and compost (1:1) for hardening. The plantlets were kept in a polychamber at $80 \%$ relative humidity, $32 \pm 2{ }^{\circ} \mathrm{C}$ tempera- tures for a $12 \mathrm{~h}$ photoperiod under $1500 \mathrm{lux} / \mathrm{m}^{2}$ sun light for acclimation. Established plants were transplanted in earthen pots under natural conditions and the survival rate was recorded.

All experiments were repeated three times. Each treatment had 15 replicates. The morphologenetic response of explants for microshoot induction was evaluated in eight weeks of culture. For microshoots proliferation and plantlet formation, results were evaluated in eight weeks of culture. Morphogenetic response was expressed as percentage of explants with microshoots in relation to the number of surviving explants. For acclimatization 50 or 25 plantlets were taken for each treatment. Data were statistically analyzed and in
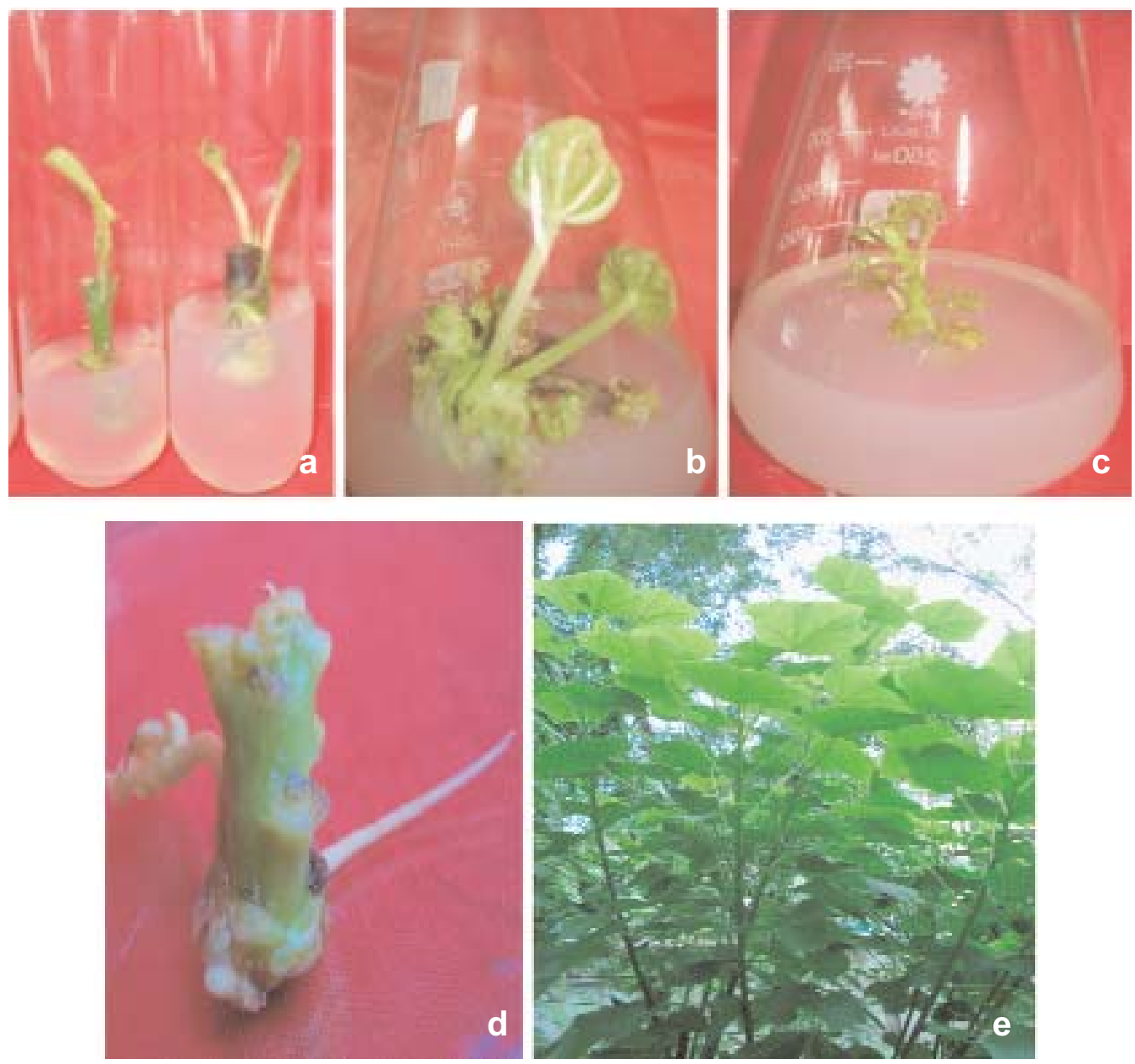

Fig. 1. In vitro regeneration of Jatropha curcas L. from nodal explants.

(a) Induction of shoots from nodal explants after three weeks. (b) Development and multiplication of shoots from nodal explants after six weeks. (c) Development and multiplication of shoots from nodal explants after nine weeks. (d) Rooting of in vitro regenerated shoots cultured in three weeks. (e) Acclimatized regenerated plants of one year old. 
some parameters means were compared using DMRT (Duncan, 1955).

\section{Results and discussion}

Shoot tip and nodal explants of Jatropha curcas L. were cultured on MS media supplemented with various concentration of BAP alone and with NAA or IAA for multiple shoot regeneration. The explants were found to be swollen and they produced two to three shoots within three weeks after inoculation (Fig.1a) on MS media containing BAP alone but the number of shoots increased up to $7.2 \pm 0.68$ when the explants were cultured in MS with $1.5 \mathrm{mg} / \mathrm{l} \mathrm{BAP}+0.5 \mathrm{mg} / \mathrm{l}$ NAA (Table I, Fig.1b). Both the explants responded in the same medium but highest numbers of micro shoots were observed from nodal explants (Fig.1c). Combinations of BAP alone or BAP with IAA were not suitable than BAP with NAA for shoot induction (Table I). Kalimuthu et al. (2007) reported that the biodiesel plant, Jatropha curcas was micropropagated using nodal explants on MS supplemented with $1.5 \mathrm{mg} / 1 \mathrm{BAP}, 0.5 \mathrm{mg} / \mathrm{Kn}$ and $0.1 \mathrm{mg} / \mathrm{l} \mathrm{IAA}$ and somatic embryos were induced directly from green cotyledon explants on MS fortified with $2.0 \mathrm{mg} / 1$ BAP. In Jatropha curcas and other medicinal plants, it was also observed that multiple shoots were found by using different concentration of cytokinin with auxins by others (Faisal et al., 2003;

Table II. Effect of IBA, NAA and IAA on root induction in regenerated shoots of Jatropha curcas on half strength MS.

\begin{tabular}{ccccc}
\hline $\begin{array}{c}\text { Growth regulators } \\
(\mathrm{mg} / \mathrm{l})\end{array}$ & $\begin{array}{c}\text { \% of shoots pro- } \\
\text { ducing roots }( \pm \mathrm{SE})\end{array}$ & $\begin{array}{c}\text { No. of roots/ } \\
\text { shoot }( \pm \mathrm{SE})\end{array}$ \\
\hline BAP & NAA & IAA & & \\
\hline 0.5 & & & $47.2 \pm 1.53 \mathrm{i}$ & $1.2 \pm 0.65 \mathrm{~d}$ \\
0.75 & & & $53.2 \pm 1.46 \mathrm{hi}$ & $1.8 \pm 0.65 \mathrm{~cd}$ \\
1.0 & & & $61.0 \pm 0.10 \mathrm{fgh}$ & $2.2 \pm 0.76 \mathrm{bcd}$ \\
1.5 & & & $57.8 \pm 1.85 \mathrm{~g}$ & $1.6 \pm 0.72 \mathrm{cde}$ \\
& 0.5 & & $54.2 \pm 1.53 \mathrm{~h}$ & $1.2 \pm 0.76 \mathrm{~d}$ \\
& 0.75 & & $62.0 \pm 0.71 \mathrm{f}$ & $2.0 \pm 0.63 \mathrm{c}$ \\
& 1.0 & & $69.4 \pm 1.08 \mathrm{c}$ & $2.8 \pm 0.59 \mathrm{~b}$ \\
& 1.5 & & $65.2 \pm 1.16 \mathrm{e}$ & $2.2 \pm 0.71 \mathrm{bcd}$ \\
& & 0.5 & $61.4 \pm 0.75 \mathrm{fg}$ & $1.8 \pm 0.65 \mathrm{~cd}$ \\
& 0.75 & $72.6 \pm 0.93 \mathrm{~b}$ & $2.6 \pm 0.96 \mathrm{bc}$ \\
& $\mathbf{1 . 0}$ & $\mathbf{8 4 . 4} \pm \mathbf{1 . 1 6} \mathbf{~ a}$ & $\mathbf{3 . 6} \pm \mathbf{0 . 7 2} \mathbf{a}$ \\
& 1.5 & $68.2 \pm 0.71 \mathrm{~d}$ & $2.2 \pm 0.63 \mathrm{bcd}$ \\
\hline
\end{tabular}

Mallikadevi et al., 2008; Sahoo and Debata, 1998; Spera et al. 1997; Sujatha and Mukta, 1996; Sujatha et al. 2005). $84.4 \%$ regenerated shoots rooted (Fig.1d) when cultured individually on root induction medium consisted of halfstrength MS medium with $1.0 \mathrm{mg} / \mathrm{l}$ IAA (Table II). Use of auxins singly or in combination for rooting was also reported by others (Baskaran and Jayabalan, 2005; Bhadra et al., 2009; Hassan and Khatun, 2010; Sivakumar and Krishnamurthy, 2000).

About 85 per cent of the transplanted plants of Jatropha curcas survived if the plants in the rooting culture tubes were kept in normal room temperature for seven days before transplantation in pots and reared for three weeks. The plantlets were reared under semi-controlled temperature (30 $\pm 2^{\circ} \mathrm{C}$ ) and light (1500 lux) in a chamber with 80 per cent humidity. During this period of acclimation shoots elongated, leaves expanded and turned to deep green and healthier (Fig.1e).

Following the transfer of plants to an open place and gradually acclimatized to outdoor conditions, where 85 per cent plants were survived. The technique described here appears to be readily adaptable for large scale plant regeneration and plantation of Jatropha curcas.

\section{Acknowledgement}

The authors are indebted to Mr. Abu Anis Jahangir, Director, BCSIR Laboratories, Dhaka and grateful acknowledgement is also due to Professor Elias Khan, Principal, Savar College, Savar, Dhaka for their kind permission, sincere suggestions and moral support during research work.

\section{References}

Banerji R, Chowdhury AR, Misra G, Sudarsanam G, Verma SC and Srivastava GS (1985), Jatropha seed oils for energy. Biomass 8: 277-282.

Bhadra SK, Akhter T and Hossain MM (2009), In vitro micropropagation of Plumbago indica L. through induction of direct and indirect organogenesis. Plant Tissue Cult. and Biotech. 19 (2): 169-175.

Baskaran P and Jayabalan N (2005), An efficient micropropagation system for Eclipta alba - a valuable medicinal herb. In Vitro Cell. Dev. Biol. Plant. 41: 532-539. 
Dehgan B and Webster GL (1979), Morphology and intrageneric relationships of the genus Jatropha. University Calif. Publication in Botany. 74.

Duncan DB (1955), Multiple range and multiple F-tests. Biometrics 11: 1-42.

Faisal M, Ahmad N and Anis M (2003), Shoot multiplication in Rauvolfia tetraphylla L. using thidiazuron. Plant Cell Tiss. Organ. Cult., 80: 187-190.

Ghani A (2003), Medicinal Plants of Bangladesh with Chemical Constituents and Uses. 2nd Ed. (Asiatic Military Press, Dhaka, 1000). pp. 269.

Godbole SR, Pandse GS and Badekar VS (1966), Glossary of Vegetable Drugs in Vegbhatt. Published by Dr. G. S. Pandse for IDRA, Poona, India.

Hassan AKMS and Roy SK (2005), Micropropagation of Gloriosa superba L. through high frequency shoot proliferation. Plant Tissue Cult. and Biotech. 15(1): 67-74.

Hassan AKMS and Khatun R (2010), Regeneration of Ficus glomerata Roxb., using Shoot tips and Nodal explants. Bangladesh Journal of Botany. 39(1): 47-50.

Heller J (1996), Physic nut. Jatropha curcas L. promoting the conservation and use of under utilized and neglected crops. 1. Institute of Plant Genetic and Crop Plant Research, Gatersleben/ International Plant Genetic Resource Institute, Rome.

Kalimuthu K, Paulsamy S, Senthilkumar R and Sathya M (2007), In vitro propagation of the biodiesel plant Jatropha curcas L. Plant Tissue Cult. and Biotech. 17 (2): 137-147.

Lui Z and Li Z (2001), Micropropagation of Camptotheca acuminata Decaisne from axillary buds, shoot tips and seed embryos in tissue culture system. In Vitro Cell Dev. Biol. Plant. 37: 84-88.

Mallikadevi T, Senthilkumar P and Paulsamy S (2008), In vitro regeneration of the medicinal plant, Plumbago zeylanica $\mathrm{L}$. with reference to a unique population in Maruthamalai, the western ghats, India. Plant Tissue Cult. and Biotech., 18 (2): 173-179.
Martin G and Mayeux A (1985), Curcas oil (Jatropha curcas L.): A possible fuel. Agric. Trop. 9: 73-75.

Martin KP (2002), Rapid propagation of Holostema adakodien Schult. A rare medicinal plant, through axillary bud multiplication and indirect organogenesis. Plant Cell Rep. 21: 112-117.

Martin KP (2003), Plant regeneration through somatic embryogenesis on Holostema ada-kodien Schult. a rare medicinal plant. Plant Cell Tiss. Orga. Cult. 72: 79-82.

Muhlbauer W, Esper A, Stumpf E and Baumann R (1998), Workshop report - Rural energy, equity and employment: Role of Jatropha curcas. The Rockefeller Foundation, Scientific Center (SIRDC). Zimbabwe; May, 13-15.

Murashige T and Skoog F (1962), A revised medium for rapid growth and bioassays with tobacco tissue culture. Physiol. Plant. 15: 473-479.

Rojore S and Batra A (2005), Efficient plant regeneration via shoot tip explants in Jatropha curcas L. J. Plant Biochemistry and Biotechnology, 14: 73-75.

Roy S (1990), Effect of various factors on growth and productivity of Jatropha curcas, a hydrocarbon yielding plant. In: Grassi G., Gosses G. and dos Santos G. (Eds.). Biomass for Energy and Industry Vol. I. Elsevier applied Sci. Publication, London and New York; pp.1484-1488.

Sahoo S and Debata B K (1998), Micropropagation of Plumbago zeylanica Linn. Journal of Herbs, Spices \& Medicinal Plants. 5(4): 87-93.

Sivakumar G and Krishnamurthy KV (2000), Micropropagation of Gloriosa superba L.- an endangered species of Asia and Africa. Current Scence. 78(1): 30-32.

Spera MRN, Pasqual M, Maciel ALR and Salvador ED (1997), Effect of different concentration of $\mathrm{Kn}$ and 2$4 \mathrm{D}$ on the in vitro cultivation of Jatropha podagrica Hook'roots. Ciencia e Agrotecnologia 21: 386-389. 
Sujatha M and Dhingra M (1993), Rapid plant regeneration from various explants of Jatropha integerrima. Plant Cell Tissue and Organ Cult. (Netherlands). 35: 293296.

Sujatha M. and Mukta N (1996), Morphogenesis and plant regeneration from tissue culture of Jatropha curcas. Plant Cell Tissue and Organ Cult. (Netherlands). 44: 135-141.

Sujatha M, Makkar H P S and Becker K (2005), Shoot bud proliferation from axillary nodes and leaf section of nontoxic Jatropha curcas L. Plant Growth regulatio. 47: 83-90.
Sujatha M and Prabakaran AJ (2003), New ornamental Jatropha hybrids through interspecific hybridization. Genetic resource and Crop Evo. 50: 75-82.

Takeda Y (1982), Development study on Jatropha curcas (Sabu dum) oil as a substitute for diesel engine oil in Thailand. J. Agric. Assoc. China. 120: 1-8.

Received: 18 October 2012; Revised: 20 January 2013; Accepted: 17 December 2013. 